\title{
Apoplexy in Sellar Metastasis: A Case Report and Review of Literature
}

\author{
Sella Metastazında Apopleksi: Bir Olgu Sunumu ve Literatürün Gözden \\ Geçirilmesi
}

Sarbjit Singh CHHIBER ${ }^{1}$, Abdul Rashid BHAT ${ }^{1}$, Shoukat H KHAN ${ }^{2}$, Mohd Afzal WANI ${ }^{1}$, Altaf U RAMZAN ${ }^{1}$, Altaf R KIRMANI ${ }^{1}$, Nayel K MALIK ${ }^{1}$, Abrar A WANI ${ }^{1}$, Tanveer RATHER ${ }^{2}$

${ }^{1}$ Sher-i-Kashmir Institute of Medical Sciences Soura, Department of Neurosurgery, Srinager/ J\&K, India

${ }^{2}$ Sher-i-Kashmir Institute of Medical Sciences Soura, Department of Nuclear Medicine, Srinagar/ J\&K, India

Correspondence address: Sarbjit Singh CHHIBER / E-mail: sarabjitchhiber@gmai.com

\begin{abstract}
Apoplexy in sellar metastasis is very rare with only a few case reports in literature. A case of apoplexy in sellar metastasis from follicular thyroid carcinoma is reported and the literature is briefly reviewed. The patient presented with sudden onset headache and bi-lateral loss of vision following thyroidectomy in a case of follicular carcinoma thyroid with proven sellar metastasis. CT scan showed hyperdense blood in sellar mass suggestive of apoplexy in sellar metastasis. The patient underwent early trans-sphenoidal decompression. Apoplexy in sellar metastasis, although very rare, can be clinico-radiologically indistinguishable from pituitary apoplexy and should be especially considered in the differential diagnosis of patients with known primary neoplastic disease. In view of similar patho-physiological mechanism, sellar metastasis with apoplexy should be managed in a similar manner as pituitary apoplexy.
\end{abstract}

KEYWORDS: Apoplexy, Sellar metastasis, Pituitary tumor, Follicular carcinoma thyroid

öz

Sella metastazlarında apopleksi çok nadir görülür ve literatürde sadece birkaç olgu sunumu vardır. Foliküler tiroid karsinomundan kaynaklanan bir sella metastazında apopleksi olgusu bildirilmiştir ve literatür kısaca gözden geçirilmiştir. Kanıtlanmış sella metastazlı bir foliküler tiroid karsinomu olgusunda hasta tiroidektomi sonrası ani başlayan başağrısı ve bilateral görme kaybı ile başvurdu. BT selladaki kitlede hiperdens kan gösteriyordu ve bu da sella metastazının apopleksisini destekliyordu. Hastaya erken dönemde transsfenoidal dekompresyon uygulandı. Sella metastazlarında apopleksi çok nadir olmasına rağmen klinik-radyolojik olarak pituiter apopleksiden ayırt edilemez olabilir ve özellikle bilinen primer neoplazisi olan hastaların ayırıcı tanılarında göz önünde bulundurulmalıdır. Benzer pato-fizyolojik mekanizmaların ışığında sella metastazları apopleksisi pituiter apopleksiyle benzer şekilde tedavi edilmelidir.

ANAHTAR SÖZCÜKLER: Apopleksi, Sella metastazı, Pituiter tümör, Tiroid foliküler karsinomu

\section{INTRODUCTION}

Sellar metastasis is relatively uncommon with reported incidence varying between $1 \%$ to $8 \%$ of cancers discovered elsewhere in the body (18). The presentation of patient with SM may be indistinguishable from pituitary adenomas (18) but SM undergoing hemorrhagic necrosis and presenting clinically as PA is very rare $(1,5,6,7,9,10,11,12,14,17)$. We report a case of apoplexy in sellar metastasis from follicular carcinoma thyroid.

\section{CASE REPORT}

A 65-year-old female with a long-standing neck swelling presented to an ophthalmologist with a history of gradually decreasing visual acuity in both eyes (right $>$ left) for the last 10 months and recent onset ptosis of the right eye. Her visual acuity was $6 / 36$ in right eye and 6/24 in the left eye.
The patient had bi-temporal field defects with partial III nerve palsy on the right side and pallor of the nasal half of bilateral optic discs. MRI showed a sellar mass with suprasellar extension as well as extension into bilateral cavernous sinuses (engulfment of B/L carotid arteries, right > left) (Figure 1). The patient was referred to the neurosurgery department where examination confirmed the above findings. Due to irregularity of the thyroid swelling, FNAC was requested which showed follicular carcinoma of thyroid. Tc-99m MDP and lodine 131 scan showed increased tracer uptake in the region of the thyroid gland, sella turcica and basisphenoid thus confirming the diagnosis of follicular carcinoma of thyroid with SM. Her hormonal profile (thyroid functions, cortisol and prolactin) was normal. The patient underwent total thyroidectomy. Histopathology confirmed follicular carcinoma of thyroid. In view of her age and metastatic disease, high-dose radioiodine 
ablation was planned for the SM by the department of nuclear medicine. Two weeks after thyroidectomy, she again presented with sudden onset of severe headache associated with total loss of vision in both eyes. Examination revealed loss of perception of light in both eye and bilateral ophthalmoplegia. Bilateral pupillary reflexes were absent. CT scan showed blood density within the sellar mass. A diagnosis of SM with apoplexy was made (Figure 2A, B). The patient was given high doses of steroids and was taken to surgery for trans-sphenoidal decompression. On opening the sellar dura,

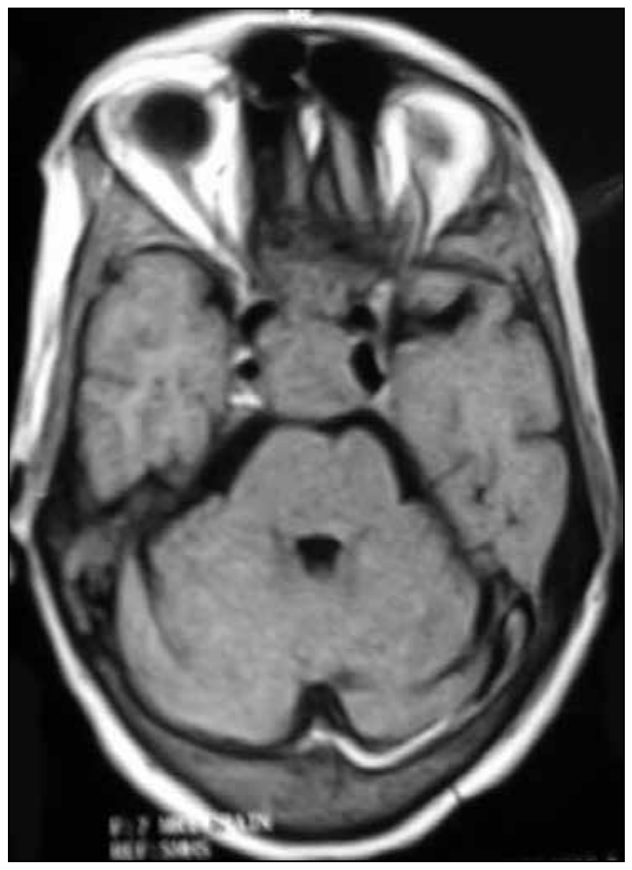

Figure 1: MRI showing mass in sellar region involving both the cavernous sinuses. dark-coloured thick blood was seen flowing out which was collected for examination. After removal of the blood, the sella appeared empty but the descent of diaphragma sella was not observed under the microscope. In view of the constant trickle of blood and cavernous sinus invasion, curettage of sella was done cautiously but did not yield any tumor tissue. Histopathological examination revealed blood mixed with necrotic tissue (hemorrhagic necrosis). Postoperatively the headache disappeared and the ophthalmoplegia improved in both eyes. Improvement of vision was not so impressive with the right eye showing perception of light and the left eye showing hand movements only. The postoperative hormonal profile showed hypothyroidism and hypocortisolism. Appropriate hormone replacements were started and she was referred back to nuclear medicine for radio-ablation of metastasis. High dose radio-ablation with radioiodine was carried out. Post radio-ablation Tc-99m MDP scan revealed systemic progression of metastatic disease to appendicular skeleton as well as the base of skull. Finally one year after surgical decompression she succumbed to metastatic disease.

\section{DISCUSSION}

Pituitary apoplexy a rare but life-threatening condition resulting from rapid enlargement of a pituitary adenoma because of hemorrhage or infarction $(2,16)$. Apoplexy is of sudden onset and may be characterized by sudden headache, visual disturbance, ophthalmoplegia, pituitary hypofunction, physical collapse, altered sensorium and death (16). Our patient conforms to the above definition of clinical apoplexy.

Although PA typically occurs in pituitary macroadenoma, it has been described in the normal pituitary gland, craniopharyngioma and lymphocytic hypophysitis $(2,16)$. A syndrome clinically similar to PA in a known case of SM is very
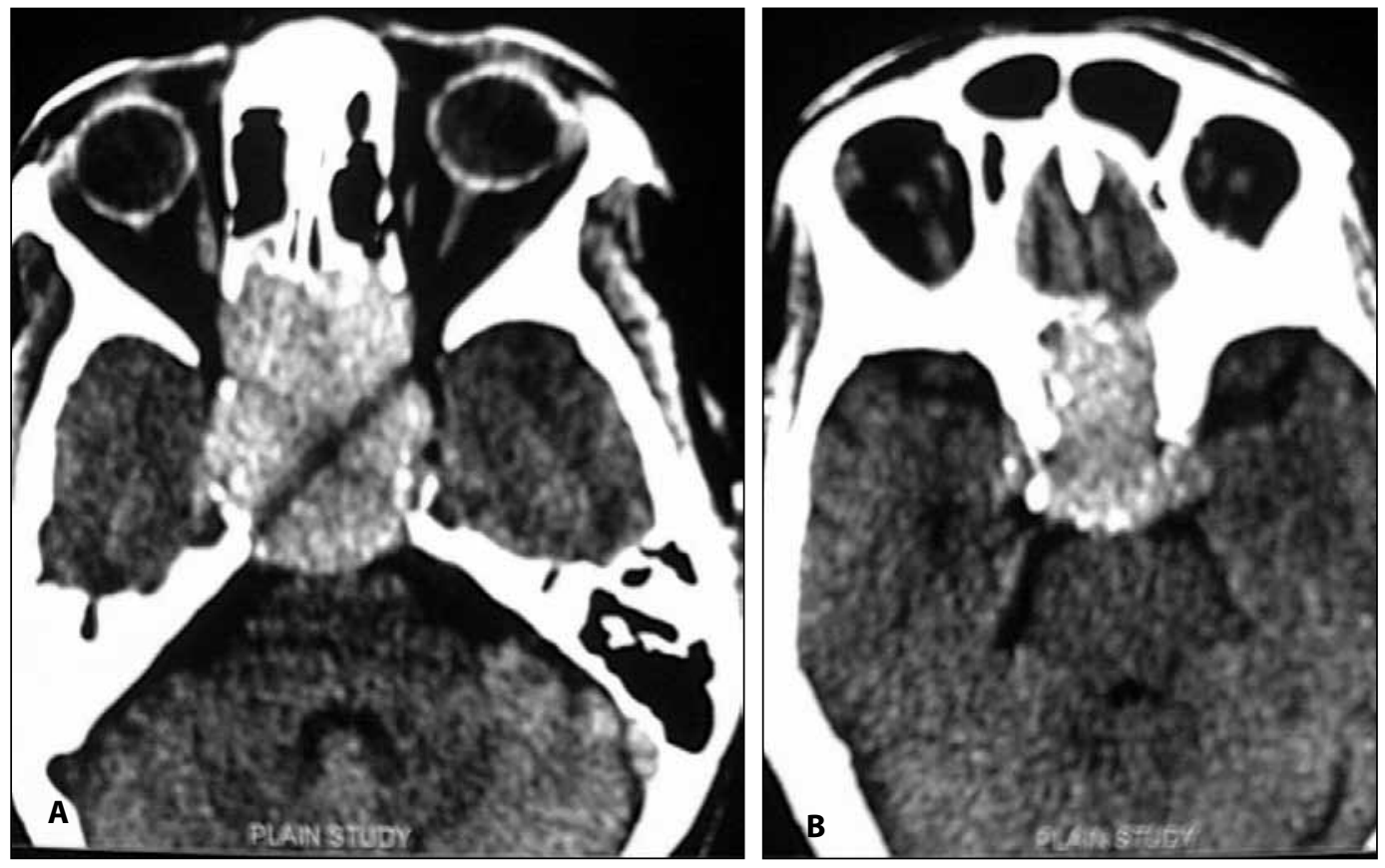

Figure 2A,B: Plain CT scan showing blood density in sellar mass suggestive of apoplexy. 
rare and only ten cases have been reported in literature up to September 2009 (Table I). One case of PA in SM, thought to be a corticotrophic pituitary adenoma was discovered at autopsy (5). PA in SM was the first presentation of primary disease in two cases $(5,9)$ whereas the rest of the cases were known patients of malignant diseases $(1,6,7,10,11,12,14,17)$. The case reported by Pallud et al. (12) had already undergone trans-sphenoidal decompression for SM from renal cell carcinoma when he presented with hydrocephalus. CSF examination showed old hemorrhage with metastatic cells. It was assumed that intra-ventricular extension of the blood from apoplexy in SM was responsible for hydrocephalus. All patients underwent trans-sphenoidal decompression. Blood mixed with neoplastic tissue was seen in all the biopsies. SM

Table I

\begin{tabular}{|c|c|c|c|c|c|c|c|}
\hline \multirow[b]{2}{*}{ Authors } & \multirow[b]{2}{*}{ Age } & \multirow[b]{2}{*}{ Sex } & \multicolumn{2}{|c|}{ Primary neoplastic disease } & \multirow{2}{*}{$\begin{array}{l}\text { Clinical } \\
\text { presentation }\end{array}$} & \multirow{2}{*}{$\begin{array}{l}\text { Surgical } \\
\text { intervention }\end{array}$} & \multirow[b]{2}{*}{ Biopsy } \\
\hline & & & $\begin{array}{c}\text { Known at time } \\
\text { of PA }\end{array}$ & $\begin{array}{l}\text { Presented as } \\
\text { PA (occult) }\end{array}$ & & & \\
\hline $\begin{array}{l}\text { Anderson } \\
\text { et al (1). }\end{array}$ & 81 & $M$ & $\begin{array}{l}\text { Prostatic } \\
\text { carcinoma. }\end{array}$ & - & $\begin{array}{l}\text { Headache, visual } \\
\text { deterioration, } \\
\text { diabetes inspidus. }\end{array}$ & $\begin{array}{l}\text { Trans-sphenoidal } \\
\text { decompression. }\end{array}$ & $\begin{array}{l}\text { Adenocarcinoma } \\
\text { Prostate + blood. }\end{array}$ \\
\hline $\begin{array}{l}\text { Chandra } \\
\text { et al (5). }\end{array}$ & - & $\mathrm{F}$ & - & $\begin{array}{l}\text { Lung } \\
\text { carcinoma } \\
\text { (autopsy). }\end{array}$ & $\begin{array}{l}\text { Headache, } \\
\text { vomiting, visual } \\
\text { deterioration, } \\
\text { Cushing's } \\
\text { syndrome. }\end{array}$ & - & $\begin{array}{l}\text { At autopsy: small cell } \\
\text { carcinoma lung. }\end{array}$ \\
\hline $\begin{array}{l}\text { Furuta et } \\
\text { al (6). }\end{array}$ & 70 & M & $\begin{array}{l}\text { Urinary bladder } \\
\text { carcinoma. }\end{array}$ & - & $\begin{array}{l}\text { Headache, } \\
\text { vomiting, visual } \\
\text { deterioration. }\end{array}$ & $\begin{array}{l}\text { Trans-sphenoidal } \\
\text { decompression. }\end{array}$ & $\begin{array}{c}\text { Transitional cell } \\
\text { carcinoma + blood. }\end{array}$ \\
\hline $\begin{array}{l}\text { Hanna et } \\
\text { al (9). }\end{array}$ & 42 & $\mathrm{~F}$ & - & Lung carcinoma. & $\begin{array}{l}\text { Meningism, } \\
\text { altered sensorium. }\end{array}$ & $\begin{array}{l}\text { Trans-sphenoidal } \\
\text { decompression. }\end{array}$ & $\begin{array}{c}\text { Moderately } \\
\text { differentiated } \\
\text { adenocarcinoma lung } \\
\text { + prolactinoma + } \\
\text { blood. }\end{array}$ \\
\hline $\begin{array}{l}\text { Julian et al } \\
\text { (10). }\end{array}$ & - & $\mathrm{F}$ & $\begin{array}{l}\text { Ovarian } \\
\text { cystadeno- } \\
\text { carcinoma }\end{array}$ & - & $\begin{array}{l}\text { Unilateral visual } \\
\text { loss. }\end{array}$ & $\begin{array}{l}\text { Trans-sphenoidal } \\
\text { decompression. }\end{array}$ & $\begin{array}{c}\text { Papillary } \\
\text { cystadenocarcinoma } \\
+ \text { blood. }\end{array}$ \\
\hline $\begin{array}{l}\text { Leishke et } \\
\text { al (11). }\end{array}$ & - & $\mathrm{F}$ & $\begin{array}{l}\text { Carcinoma } \\
\text { uterus }\end{array}$ & - & $\begin{array}{l}\text { Headache, visual } \\
\text { deterioration. }\end{array}$ & $\begin{array}{l}\text { Trans-sphenoidal } \\
\text { decompression. }\end{array}$ & \\
\hline $\begin{array}{l}\text { Qwevedo } \\
\text { et al (14). }\end{array}$ & 54 & $M$ & $\begin{array}{l}\text { Renal cell } \\
\text { carcinoma }\end{array}$ & - & $\begin{array}{c}\text { Headache, } \\
\text { vomiting, ptosis. }\end{array}$ & $\begin{array}{l}\text { Trans-sphenoidal } \\
\text { decompression. }\end{array}$ & $\begin{array}{l}\text { Renal cell carcinoma } \\
+ \text { blood }\end{array}$ \\
\hline $\begin{array}{l}\text { Tomita et } \\
\text { al (17) }\end{array}$ & 55 & M & $\begin{array}{l}\text { Sigmoid colon } \\
\text { carcinoma } \\
\text { with parietal } \\
\text { metastatic brain } \\
\text { tumor }\end{array}$ & - & $\begin{array}{c}\text { Headache, } \\
\text { unilateral visual } \\
\text { deterioration }\end{array}$ & $\begin{array}{l}\text { Trans-sphenoidal } \\
\text { decompression. }\end{array}$ & $\begin{array}{l}\text { Adeno-carcinoma } \\
\text { colon + blood. }\end{array}$ \\
\hline $\begin{array}{l}\text { Pallud et } \\
\text { al (12) }\end{array}$ & 70 & $M$ & $\begin{array}{l}\text { Renal cell } \\
\text { carcinoma. }\end{array}$ & - & $\begin{array}{l}\text { Hydrocephalus } \\
\text { secondary to } \\
\text { asymptomatic } \\
\text { apoplexy with } \\
\text { intra-ventricular } \\
\text { hemorrhage. }\end{array}$ & $\begin{array}{c}\text { Ventriculo- } \\
\text { peritoneal shunt. }\end{array}$ & $\begin{array}{l}\text { CSF analysis; few } \\
\text { renal carcinoma cells. }\end{array}$ \\
\hline $\begin{array}{l}\text { Golkawski } \\
\text { et al (7) }\end{array}$ & 46 & $\mathrm{~F}$ & $\begin{array}{l}\text { Renal cell } \\
\text { carcinoma. }\end{array}$ & - & $\begin{array}{l}\text { Headache, visual } \\
\text { deterioration. }\end{array}$ & $\begin{array}{l}\text { Trans-sphenoidal } \\
\text { decompression. }\end{array}$ & $\begin{array}{l}\text { Renal cell carcinoma } \\
\quad+\text { blood. }\end{array}$ \\
\hline $\begin{array}{l}\text { Present } \\
\text { case }\end{array}$ & 65 & $\mathrm{~F}$ & $\begin{array}{l}\text { Follicular } \\
\text { carcinoma } \\
\text { thyroid. }\end{array}$ & - & $\begin{array}{l}\text { Headache, } \\
\text { vomiting, visual } \\
\text { deterioration. }\end{array}$ & $\begin{array}{l}\text { Trans-sphenoidal } \\
\text { decompression. }\end{array}$ & $\begin{array}{c}\text { Blood + necrotic } \\
\text { tissue. }\end{array}$ \\
\hline
\end{tabular}


from renal cell carcinoma is the commonest form of SM to undergo apoplexy in the cases reported in literature (3/9). Our case was a 65-year-old female who had a known SM from follicular thyroid carcinoma and was being treated for the same and presented with a clinico-radiological picture indistinguishable from PA. Biopsy showed blood mixed with necrotic tissue but lodine 131 and Tc-99 MDP scan proved beyond doubt that sellar metastasis was from the thyroid gland. To the best of our knowledge it is the first case of metastatic follicular thyroid carcinoma presenting as PA.

The differential diagnosis of PA includes aneurismal $\mathrm{SAH}$, meningitis, stroke, migraine, optic neuritis, cavernous sinus thrombosis, encephalitis, pituitary abscess, sinusitis and myocardial infarction $(4,16)$. Apoplexy in a case of SM may be the first presentation of primary disease (9). In view of the cases reported in literature, SM should also be included in the differential diagnosis of PA especially in known cases of primary neoplastic disorders.

Precipitants of PA can be divided into four categories; a) reduced blood flow with rapid growth of tumor outstripping its own blood supply, b) acute increase in blood flow, c) endocrine stimulation of the pituitary gland and $d$ ) the anti-coagulated state (3). Intrinsic vasculopathy in pituitary tumors rendering them more susceptible to infarction and hemorrhage explains the vascular event in apoplexy (4). In light of the above mechanisms we put forward the following hypothesis for the occurrence of apoplexy in our patient. Following thyroidectomy, the decrease in serum levels of T3 and T4 hormone would have resulted in offsetting the strong negative feedback on TRH and TSH resulting in their increased blood levels leading to stimulation of SM. In the presence of vasculopathy, it might have resulted in hemorrhagic necrosis of SM. In view of our case report, recombinant TRH should be used cautiously in functional thyroid tumors with SM for radio-ablation.

MRI is the investigation of choice for sellar pathology $(2,15,16,18)$. In case the patient is very sick or MRI is unavailable, CT scan is helpful and can show blood density within the sellar mass $(13,16)$. Hyperdense blood within the sellar mass on CT scan confirmed the diagnosis of apoplexy in our patient.

Immediate institution of high dose corticosteroid therapy and trans-sphenoidal decompression are the main stay treatment for PA $(2,4,16)$ but there is some disagreement with regard to surgical treatment $(4,8,16)$. Some authors have reported better results with early decompression $(2,16)$. Others (8) concluded that patients with visual impairment or diminished level of consciousness would benefit from surgery whereas conservative treatment was as effective as surgery in patients with ophthalmoplegia. All the cases of SM with apoplexy reported in the literature underwent transsphenoidal decompression $(1,6,7,9,10,11,12,14,17)$. In terms of visual outcome, they reported mixed results with one report showing complete reversal of unilateral visual loss (10).
Our patient had marginal improvement in vision but a definite improvement in ophthalmoplegia following decompression.

In view of the similarity in the pathophysiological mechanism, SM with apoplexy should be treated in a manner similar to PA and we recommend the guidelines proposed by Semple et al (16). According to the authors, emergency surgery is required in case of deteriorating vision, sudden onset of blindness, or diminished level of consciousness. Early surgery within the first week is recommended in case of visual impairment. In case the patient is seen some time after ictus (days or weeks) and shows a stable or improving ophthalmoplegia, conservative treatment is justified.

Another issue which requires attention is the management of residual metastatic disease once the patient has undergone treatment for apoplexy. Although there are no established therapeutic guidelines, the SM should be treated as systemic disease with chemotherapy, radiotherapy or more recently with gamma knife (18).

\section{CONCLUSION}

Apoplexy in SM although very rare can be indistinguishable clinically and radiologically from PA and should be considered especially in the differential diagnosis of patients with known primary neoplastic disease. In view of similar pathophysiological mechanism, SM with apoplexy should be managed in a similar way as PA with high dose steroids and early trans-sphenoidal decompression. Although there are no established therapeutic guidelines, the residual sellar metastatic disease should be treated as systemic disease.

Abbreviations. PA: pituitary apoplexy, SM: sellar metastasis, SAH: subarachnoid hemorrhage, TRH: thyrotropin-release hormone, TSH: thyroid-stimulating hormone, MRI: magnetic resonance imaging.

\section{ACKNOWLEDGEMENTS}

We thank Javaid A. Qureshi for his secretarial assistance.

\section{REFERENCES}

1. Anderson DF, Afshar F, Toma N: Metastatic Prostatic adenocarcinoma presenting as complete ophthalmoplegia from pituitary apoplexy. Br J Ophthalmol 78 (4): 315-316, 1994

2. Bills DC, Meyer FB, Laws ER Jr, Davis DH, Ebersold MJ, Scheithauer BW, Ilstrup DM, Abboud CF: A retrospective analysis of pituitary apoplexy. Neurosurgery 33:602-609, 1993

3. Biousse V, Newman NJ, Oyesiku NM: Precipitating factors in pituitary apoplexy. Neurol Neurosurg Psychiatry 71:542-545, 2001

4. Cardoso ER, Peterson EW: Pituitary apoplexy: A review, Neurosurgery 14:363-373, 1984

5. Chandra V, McDonald LW, Anderson RJ: Metastatic small cell carcinoma of lung presenting as pituitary apoplexy and Cushing's syndrome. J Neuro-oncol 2:59-66,1984

6. Furuta S, Hatakeyama T, Zenke K, Fukumoto S: Pituitary metastasis from carcinoma urinary bladder mimicking pituitary apoplexyCase report. Neurol Med Chir (Tokyo) 39(2):165-168, 1999 
7. Golkawski F, Trofimiuk M, Czepko R, Buziak-Bereza M, Lopatka P, Adamek D, Baldys-Waligorska A, Huszno B: Two rare cases of pituitary metastasis from breast and kidney cancer. Exp Clin Endocrinol Diabetes 115(8): 537-540, 2007

8. Gruber A, Clayton J, Kumar S, Robertson I, Howlett TA, Mansell P: Pituitary apoplexy: Retrospective review of 30 patients - Is surgical intervention always necessary? $\mathrm{Br} J$ Neurosurg 20: 379-385, 2006

9. Hanna FW, Williams OM, Davies JS, Dawson T, Neal J, Scanlon MF: Pituitary apoplexy following metastasis of bronchogenic adenocarcinoma to a prolactinoma. Clin Endocrinol 51(3): 377-381,1999

10. Julian W, Hedges TR, Anderson ML, Folkerth R: Surgical reversal of a subacute complete unilateral visual loss from an ovarian metastasis to the pituitary gland. Neurosurg 31(2):349-352, 1992

11. Lieschke GJ, Tress B, Chambers D: Endometrial adenocarcinoma presenting as pituitary apoplexy. Aust N Z J Med 20(1): 81-84, 1990

12. Pallud J, Nataf F, Roujeau T, Roux FX:Intraventricular haemorrhage from a renal cell carcinoma pituitary metastasis. Acta Neurochir (Wien) 147 (9): 1003-1004, 2005
13. Post MJ, David NJ, Glaser JS, Safran A: Pituitary apoplexy: Diagnosis by computed tomography. Radiology 134:665-670, 1980

14. Quevedo I, Rodriguez Portales JA, Rosenberg H, Mery J: Apoplexy in pituitary metastasis of renal cell carcinoma: Clinical case followed for 7 years. Rev Med Chil 128(9):1015-1018, 2000

15. Robert F, Delavelle J, Melanson D: The various MRI patterns of pituitary apoplexy. Eur Radiol 9:918-923, 1999

16. Semple PL, Webb MK, de Villiers JC, Laws ER Jr: Pituitary apoplexy. Neurosurgery 56:65-73, 2005

17. Tomita H, Urui S, Kokunai T, Tamaki N: A case of metastatic tumor of the pituitary gland presenting as a subarachnoid hemorrhage. No Shinkei Geka 28 (12): 1117-1120, 2000

18. Weilbaecher C, Patwardhan RV, Fowler M, Willis BK, Nanda A: Metastatic lesions involving the sella: Report of three cases and review of the literature. Neurology India 52(3): 365-368, 2004 